IJ§ER

ISSN: $2149-5939$
International Journal of Social Sciences and Education Research

Online, http://dergipark.gov.tr/ijsser

Volume: 1(1), 2015

\title{
Üniversite öğrencilerinin aile, cinsiyet rolleri ve kadına yönelik şiddete ilişkin tutumları ${ }^{1}$
}

\author{
Attitude of the university students, family, gender roles and violence towards the \\ women
}

\author{
Yücel Can²
}

\begin{abstract}
Received Date: $01 / 01 / 2015$
Accepted Date: $01 / 02$ / 2015

$\ddot{O} z$

Bu çalışmada üniversite ögrencilerinin aile, cinsiyet rolleri ve kadına yönelik şiddete ilişkin tutumlarının belirlenmesi amaçlanmıştır. Bu amaç doğrultusunda Niğde Üniversitesi Ögrenci İşleri Daire Başkanlığı'ndan Fakülte, Yüksekokul, Meslek Yüksek Okulu, Enstitü ve Konservatuarlara ait güncel öğrenci sayıları alınmıştır. Tüm birimlere ait Fakülte, Bölüm ve Sinıf bazlı kız ve erkek ögrenci saylları alınarak bu evren üzerinden ve her sinıf bir tabaka kabul edilerek, tabakalı örneklem alma yoluna gidilmiştir. Her tabakadaki toplam ögrenci sayısının \%10'u tesadüfi örneklem belirleme yöntemiyle seçilerek bu öğrencilere anket formları uygulanmıştır. Bulguların değerlendirilmesi sonucunda ögrencilerin aile kurumuna oldukça yüksek bir değer atfederlerken, evliliğe ilişkin tutumlarının aynı derecede olumlu olmadı̆̆ gözlenmiştir. Cinsiyet rolleri konusunda özellikle erkek öğrencilerin ataerkil toplumsal cinsiyetçi yaklaşımın etkisinde kalarak cinsiyet ayrımcı tutumlara sahip oldukları gözlenmiştir. Kadına şiddetin nedenleri konusunda çok farklı nedenler ileri sürmekle birlikte; eğitimsizlik, gelenekler ve toplumun değer yargıları, erkeklerin kadınlara yönelik önyargıları ve ekonomik sorunlar kadına yönelik şiddetin en önde gelen nedenleri olarak belirtilmiştir.
\end{abstract}

Anahtar Sözcükler: Aile, evlilik, cinsiyet rolleri, kadına şiddet, gençlik

\begin{abstract}
In this study aimed to determine the attitudes of the university students' family, gender roles and violence towards the women. The population of the research covers the students of Niğde University and it has been constructed via current enrolment lists received from the Office of the Vice President for Student Affairs in December, 2014. The lists include the current number of students at faculties, vocational schools, institutes, and conservatory. Based on the numbers of boys and girls at each faculty, department and class, and assuming each class as a stratum, a stratified sampling has been constructed. $10 \%$ of the total number of students in each layer selected by random sampling method and a questionnaire has been applied to this group. The findings show that the students ascribe a considerable amount of value to the family institution. Their attitudes towards marriage, on the contrary, are not equally positive. It has been observed that especially boys on gender roles, gender approach that they have discriminatory attitudes Sexist patriarchal society the students have asserted various reasons towards the reasons of violence against women but the prominent ones described as follows: lack of education, traditions, social values, prejudices of men, and economic problems.
\end{abstract}

Keywords: Family, marriage, gender roles, violence against women, youth

\footnotetext{
${ }^{1}$ Bu makale Niğde Üniversitesi Araştırma Projeleri Birimi tarafından desteklenen SOB 2014/05-BAGEP numaralı, Üniversite Öğrencilerinin Evlilik, Aile ve Cinsiyet Rollerine İlişkin Tutumları: Niğde Üniversitesi Örneği başlıklı projenin verilerinden yararlanılarak oluşturulmuştur.

${ }_{2}$ Assoc. Prof. Dr. Niğde University, Faculty of Science and Arts, Sociology Department, NiĞGE/TURKEY, ycan@nigde.edu.tr
} 
Can, Y. (2015). Üniversite öğrencilerinin aile, cinsiyet rolleri ve kadına yönelik şiddete ilişkin tutumları. International Journal of Social Sciences and Education Research, 1 (1), 163-175.

\section{Giriş}

Aile kurumu üzerinde yoğun tartışmaların yapıldığı lehinde ve aleyhinde pek değerlendirmeye konu olan temel toplumsal kurumlardan biridir. Ailenin ekonomik ve sosyal pek çok fonksiyonunu başka kurumlara devrettiğini, artık aileye gerek kalmadığını söyleyen ve ailenin ölümü adıyla kitap yazan sosyal bilimcilerden, ailenin hiçbir zaman önemini kaybetmeyeceğini özellikle de çocuk ve gençlerin alkolizm, uyuşturucu ve küçük yaşta cinsellik gibi olumsuzluklardan korunmasında ve çocukların duygusal doyuma ulaşmasında ailenin alternatifi olmadığını, bireyin sosyalleşmesinde ve toplumsal yapının devamlılığı konularında çok önemli bir işlev göreceğini ileri süren anlayışlara kadar pek çok farklı görüşe rastlamaktayız.

Bütün bu tartışmaların önemli bir kısmının temelinde aile kurumuna ilişkin olumlu ya da olumsuz önceden var olan ve büyük oranda ön kabullerden beslenen yaklaşımların etkili olduğunu görüyoruz. Kendini çatışmacı teori içinde gören ve tüm toplumsal ilişkilerin temelinde ve tarihin itici gücü olarak çatışmayı ele alan yaklaşımlar, ailenin devlet-sermaye-erkek ataerkil erkek ittifakının lehine, sivil toplum-işçi sınıfı-kadın üçlüsünün ise aleyhine işleyen en önemli kurumlarından biri olduğunu ileri sürmüşlerdir. Kendini fonksiyonalist teori içinden tanımlayan ve toplumsal hayata ve ilişkilere daha çok uyum ve işbirliği penceresinden bakan yaklaşımlar ise, ailenin medeniyetin devamını, çocukların sosyalleşmesini sağlayan ve bireyleri suç ve sapma türü davranışlardan koruyan temel toplumsal kurumlardan biri olduğunu belirtmişlerdir. Aile kurumuna ilişkin tartışmaların aileyi toptan reddeden ve toplumsal hayata ilişkin olumsuzlukların ana sorunlularından biri gören anlayışla, aileyi mitleştiren ve aile kurumuna yöneltilen eleştirilere hiç tahammül göstermeyen yaklaşımlar arasında sıkışıp kaldığı gözlenmektedir. Bu iki uç yaklaşımın ötesinde nerdeyse insanlıkla eşit yaşta olan bu kurumun ekonomik ve sosyal değişimlerden nasıl etkilendiğinin ve nasıl bir değişime uğradığının anlaşılmaya çalışılması daha sağlıklı bir yaklaşım olacaktır. Bu da aile kurumuna ilişkin araştırmaların artmasıyla mümkün olacaktır. Bu araştırma böyle bir çabanın sonucu olarak ortaya çıkmıştır.

\section{Yöntem}

Niğde Üniversitesi örneğinde üniversite öğrencilerinin aile, evlilik, cinsiyet rolleri ve kadına şiddet konusundaki tutumlarını belirlemeye dönük olarak yapılan bu çalışmada, Niğde Üniversitesi Öğrenci İşleri Daire Başkanlığı'ndan alınan, Aralık 2014 dönemi Fakülte, Yüksekokul, Meslek Yüksek Okulu, Enstitü ve Konservatuarlara ait güncel öğrenci sayıları alınmıştır. Tüm birimlere ait Fakülte, Bölüm ve Sınıf bazlı kız ve erkek öğrenci sayıları alınarak bu evren üzerinden ve her sınıf bir tabaka kabul edilerek, tabakalı örneklem alma yoluna gidilmiştir. Her tabakadaki toplam öğrenci sayısının \%10’u tesadüfi örneklem belirleme yöntemiyle seçilerek bu öğrencilere anket formları uygulanmıştır. Öğrencilere anket uygulamasına geçilmeden önce, yirmi öğrenciyle bir pilot uygulama yapılmış, bu uygulamadan alınan geri bildirimler doğrultusunda anket formlarına son halleri verilmiştir. Anket formunda toplam otuz yedi soru bulunmaktadır. Her birimdeki toplam öğrenci sayısının \%10'u örneklem olarak seçilmiştir. Bölümler ve sınıflar bazında da örneklemler belirlenmiş ve bu örnekleme uygun sayıda öğrenciye anket formu uygulanmıştır. Anket formları öğrencilere 2015 yılı Mart, Nisan ve Mayıs ayları içerisinde uygulanmıştır.

\section{Kuramsal çerçeve}

Toplumsal olay ve olguların anlaşılmasında bireysel ihtiyaçlar, artan nüfus ve karmaşıklaşan ilişkiler örüntüsüne bağlı olarak bu ihtiyaçların sağlıklı bir şekilde tatminini sağlamak için oluşturulan toplumsal kurumlar ve kurumların bir araya gelerek oluşturduğu toplumsal yapının analiz 
Can, Y. (2015). Attitude of the university students, family, gender roles and violence towards the women. International Journal of Social Sciences and Education Research, 1 (1), 163-175.

edilmesi sosyologların en temel uğraş alanlarından birini oluşturmaktadır. Toplumsal yapıyı meydana getiren en eski ve köklü kurumlardan biri olan aile kurumu ve evlilik; ekonomik, biyolojik, psikolojik ve toplumsal pek çok işlevi üstlenmektedir. Evlilikle en temel güdülerden biri olan cinsellik düzenlenmekte, kadın ile erkek arasındaki ilişkiler meşru bir zemine oturtulmaktadır. Evlilikle birlikte kurulan aile birliği eşlerin bireysel ve toplumsal ihtiyaçlarının tatmini yanında, insan neslinin devamı ve yeni toplumun değerler sisteminin aktarılması yoluyla kuşakların toplumsallaşması işlevini de yerine getirmektedir. Ekonomik ve sosyal alandaki diğer pek çok ilişki gibi kadın ve erkeğin birlikteliğini sağlayan evlilik ilişkisi de hukuki bir zemine oturtulmuş ve tarafları yasalarla bağlayan bir resmi sözleşmeye dönüşmüştür. Son yıllarda farklı biçimlerine rastlansa da, genel anlamda bir kadınla bir erkeğin bir araya gelmesiyle oluşan evlilik ve bunun sonucunda ortaya çıan aile kurumu yasalarla da desteklenerek toplumun temeli olma özelliğine sahip bir kurum halini almıştır.

Toplumsal sistemin bir alt sistemi olan aile, topluma yeni üyelerin katılması ve toplumun devamlılığı açısından vazgeçilmez bir öneme sahiptir. Aynı zamanda aile diğer toplumsal kurumların işlevlerini yerine getirmesine de katkı sağlamaktadır. Bireylerin toplumda geçerli temel kuralları öğrenerek sosyalleşmelerini sağlar. Tüm toplumların varlıklarını ve devamlılıklarını sürdürebilmek için aile kurumuna gereksinimleri vardır. Toplumların tarihinde bilinen bütün toplumlarda kişi yaşamını aile içinde sürdürür. Temelinde ekonomik, duygusal ve cinsel doyumun bulunduğu ve toplumun en küçük birimi olan bu sosyal grubun niteliği ve işlevi, mensup olduğu toplumun kültürü tarafindan belirlenir (Özgüven, 2001:1).

Fonksiyonalist açıklamaların temel özelliği bir sistem vurgusu yapmaları ve sistemi oluşturan öğelerin sistemin işleyiş̧ine katkılarına vurgu yapmasıdır. Toplumsal yapıyı bir sistem olarak ele aldığımızda toplumsal yapıyı oluşturan aile, din, siyaset gibi kurumlar da bu sistemi meydana getiren öğeler olarak karşımıza çıkmaktadır. Bir sistem ya da yapı kavramsallaştırılırken, sistemin ve bu sistemi meydana getiren öğelerin işleyişine ilişkin şu özelliklerden söz etmek yararlı olacaktır. Öncelikli olarak bir sistemin öğeleri işlevsel olarak karşılıklı ilişki içindedirler. Öğeler karşılıklı olarak birbirlerinin işleyişine katkı sağlarlar, yani bir sistemin öğeleri bu sistemin süregiden işleyişine genellikle olumlu katkıda bulunurlar (Abrahamson, 1990:3-4). Fonksiyonalist kuramın bakış açısıyla değerlendirdiğimizde aile kurumu kendisi gibi pek çok kurumla birlikte uyum içinde çalışarak toplumsal yapının sağlıklı bir şekilde uyum içinde çalışmasına katkıda bulunan çok önemli ve faydalı bir kurumdur. Bu durumu en iyi ifade eden yargılardan biri Fonksiyonalist kuramın en önemli temsilcilerinden biri olan Parsons'ın; 'Aileler kişilikler üreten fabrikalardır’ sözü olsa gerektir (Poster, 1989:98). Parsons'ın sözünden de anlaşılacağı üzere, fonksiyonalist kuram aileyi bireyleri toplumsal hayata hazırlayan ve bireylerin topluma uyumuna katk1 yapan en temel kurumdur. Parsons özellikle çekirdek ailenin modern sanayi toplumunun en temel öğesi olduğunu vurgulayarak, ailenin çöktüğü artık işlevini yitirdiği savlarına karşılık, aile kurumunda çöküş olarak görülen şeyin değişen toplumsal koşullara uyum sürecinde yeni bir adım olduğunu dile getirmiştir. Parsons Amerika özelinden hareketle akrabalık ilişkilerinin öneminde bir azalma olduğunu ve çekirdek ailenin işlevlerinin okullar, toplumsal hizmet organizasyonları, kiliseler ve devlet gibi diğer kurumlara devredildiğini gözlemledi. Parsons bu değişimleri ailenin önemini ve değerini azaltan bir tehdit olarak değil, çekirdek ailenin önemini, değerini ve ailenin yerine getirdiği işlevlerin önemi daha çok vurgulanıyor ve aile toplum için daha önemli hale geliyordu (Poster, 1989:116). Fonksiyonalist düşünürlerin çoğu için toplumsal yapı çark gibi dişleri birbirine girmiş parçalardan oluşan bütünleşmiş bir bünyedir (Giddens, 2012:145). Fonksiyonalist kuramın aile kurumuna verdiği desteğin ardında yatan belli başlı hususlar ise; ailenin çocukların 
Can, Y. (2015). Üniversite öğrencilerinin aile, cinsiyet rolleri ve kadına yönelik şiddete ilişkin tutumları. International Journal of Social Sciences and Education Research, 1 (1), 163-175.

suç başta olmak üzere olumsuzluklara karışmasını önleyici etkisi, ahlakın temellerini sağlamlaştırması, uyuşturucu gibi olumsuz alışkanlıklardan ve erken yaşta cinsellikten koruyucu yönde etkide bulunmasıdır. Aile korumasında olmayan çocuk ve gençlerin bir takım olumsuz etkilere daha açı olacakları, aile sayesinde olumsuzluklardan daha fazla korunacakları kabul edilmektedir.

Toplumsal yapıyı ve onu oluşturan toplumsal kurumları açıklama iddiasında olan çatışmacı kuram aile kurumuna fonksiyonalist kuramın tersine çok da sıcak bakmamıştır. Çatışmacı ekole mensup kuramcılar toplumsal düzenin varolma nedeni olarak konsensüsten ziyade çatışmayı görmüşlerdir. Örneğin Marx'a göre toplumlar kaynakları eşit olmayan sınıflara bölünmüş haldedirler. Böyle belirgin eşitsizlikler var olduğundan, toplumsal sistemin içine inşa edilmiş çıkar bölünmeleri vardır. Toplum esas olarak uyumla değil gerilimle dolu olarak görülmektedir. En istikrarlı toplumsal sistemler bile birbirlerinin hasmı olan gruplaşmaların huzursuz bir dengesini temsil eder. Marx'a göre kadınlarla erkekler arasındaki otorite ve güç farklılıkları sınıfsal ayrımlar belirginleştikten sonra ortaya çıkmıştır. Evlilik ve aile kurumu aracılığıyla kadınlar erkeklerin sahip olduğu özel mülkün bir biçimi haline gelmiştir. Sınıf farklılıklarının üstesinden gelindiğinde yani sınıfsız bir toplum aşamasına ulaşıldığında kadınların erkekler karşısındaki esareti sona erecektir (Marshall, 1999:112; Giddens, 2012:148).

Feministlere göre erkeklerin geleneksel olarak toplumda güç ve yetkilerini sürdürmekte çıkarları bulunmaktadır. Bu şartlar altında toplumsal cinsiyetlendirilmiş aile gibi kurumlar kurulu toplumsal düzenlemeleri devam ettirmek ve erkek egemenliğini meşrulaştırmakta hayati bir güç haline gelir. 1980'li yılların en radikal söylemlerinden birinin feminist gruplardan geldiğini söylemek yanlış olmayacaktır. Böylece literatüre Toplumsal Cinsiyet kavramı kazandırılmıştır. Bu kavram cinsiyetin kişisel özelliklerinin ötesinde toplumsal yapılarla ve ilişkilerle bağlantılı bir boyutunun olduğu düşüncesini de içerir (Bora ve Üstün, 2008:38). Yıllarca toplumda kadınlar ve erkeklere atfedilen farklı özellikler, roller ve statülerin biyolojik olarak yani cinsiyet ile belirlendiğine, rol ve statülerin değiştirilemez olduğuna ve kadının erkeğin toplumda oynayacağı rollerin ve işgal edebileceği statülerin doğumla birlikte kadın ya da erkek olmalarına göre belirlendiği, doğal ve değiştirilemez olduğu öne sürülmüştür. Cinsiyet terimi kadın olmanın biyolojik ve fizyolojik yönünü, toplumsal cinsiyet terimi ise kadın ve erkeğin biyolojik yapısından ziyade toplumun onlardan beklentilerini ifade etmektedir. Toplumsal cinsiyet kültürel bir mahiyet arz etmekte kültürel değerlere, zamana ve yere göre değişiklik göstermektedir (Demirbilek, 2007:13).

Kadın ve erkeğin toplumdaki görevleri, sorumlulukları, hakları, maddi ve manevi kültür unsurlarının üretim sürecindeki konumları ve kişilik özelliklerini şekillendiren tüm unsurlar toplumsal cinsiyet anlayışına göre şekillendirilir. Bunun sonucunda da kadınlar özel alana erkekler ise kamusal alana yönlendirilir. Kadınlardan istenen hayatını eşi ve çocuklarına göre şekillendirmesidir. Ev işleri ve çocuk bakımı kadınların birincil görevi olarak kabul edilir (Ökten, 2009:308). Kadınların bakıp büyütme ve koruma işini erkeklerden daha iyi yaptıklarına ve bu yüzden onların doğal mekanlarının ev olduğuna ve erkeğin de ekmek parası kazanma rolünü üstlendiğine ilişkin bir mit söz konusudur (Köse, 2009:82).

Türk kültüründeki mevcut kurumların tümünü reddeden feminist gruplar, Türkiye'de söylemsel düzeyde yeni bir sayfa açtılar. Sadece kadınla ilgili mevcut politikaları değil, aynı zamanda Türk kültüründeki toplumsal dayanışmanın temeli kabul edilen aileyi ve aile ile ilgili değerlerin kaynaklandığını iddia ettikleri ataerkil sistemi de eleştirdiler. Ataerkil kültürü besleyen ve bu kültürden etkilenen ne kadar özel ve kamusal değer ya da kurum varsa hepsi feminist gruplar tarafından tartışmaya açılmış ve eleştiriye uğramıştır (Çaha, 2010:178). 
Can, Y. (2015). Attitude of the university students, family, gender roles and violence towards the women. International Journal of Social Sciences and Education Research, 1 (1), 163-175.

Ulrich Beck ve Elizabeth Beck-Gernsheim Aşkın Olağan Kaosu'nda hızla değişmekte olan bir dünyada; kişisel ilişkileri, evlilikleri ve aile örüntülerini incelemişlerdir. Onlar eskiden kişisel ilişkileri yöneten geleneklerin, kuralların ve yönergelerin artık kullanılmadığını belirtmişlerdir. Şimdi evliliklere ekonomik amaçlar için ya da ailenin yönlendirmesinden çok gönüllü olarak girilmesi özgürlükler yanında yeni gerilimleri de beraberinde getirmektedir. Çağımız aile, iş, sevgi ve bireysel hedeflerin peşine düşme özgürlüğü arasındaki çatışan çıkarların yaşandığı bir dönemdir. Bu nedenle kadınlarla erkekler arasındaki rekabetin yükselişte olması hiç de şaşırtıcı değildir. Ancak evlilik ve aile hayatı her ne kadar kırılgan görünse de, evlilik ve aile insanlar için önemli olmayı bugün de sürdürmektedirler (Giddens, 2012:284). Bu durumun nedenlerinden biri ve önemlisi kadın ile erkek arasındaki aşk ve sevgi bağı ise de, bugün özellikle çocuklar ve gençler arasında hızla artan alkol ve uyuşturucu bağımlılı̆̆ gibi zararlı alışkanlıklar, artan suç oranları ve ailenin bunlara karşı panzehir olduğu düşüncesi ailenin günümüz dünyasında yeniden keşfedilmesine de neden olmaktadır.

\section{Bulgular ve tartışma}

Araştırmanın bu bölümünde öncelikle öğrencilerin aile ve evliliğe ilişkin tutumlarına yer verilmiştir. Bu bulgulardan hareketle öğrencilerin aile ve evliliğe atfettikleri anlam belirlenmeye çalışılmıştır.

Tablo 1. Aile önemli bir kurumdur

\begin{tabular}{|l|c|c|}
\hline & Say1 & $\%$ \\
\hline Hiç katılmıorum & 10 &, 5 \\
\hline Katılmıorum & 22 & 1,2 \\
\hline Karasızım & 13 &, 7 \\
\hline Kısmen katılıorum & 74 & 4,0 \\
\hline Tamamen katılıyorum & 1731 & 93,5 \\
\hline Cevapsız & 2 &, 1 \\
\hline Toplam & 1852 & 100,0 \\
\hline
\end{tabular}

Tablo 1 incelendiğinde öğrencilerin aileye bakış açısının oldukça olumlu olduğu görülmektedir. Ailenin önemli bir kurum olduğuna tamamen katılanların \%93,5 gibi yüksek bir orana sahip olduğu görülmektedir. Öğrencilerin aile olma ve bir arada yaşamak için evliliğin olmazsa olmaz şart olduğu yönündeki düşünceye yaklaşımları da aile ile evliliğe atfedilen anlamların verilen değer ve önemin neden farklılaştığını açıklamada bize yardımcı olabilir.

Tablo 2. Evlilik gereklidir

\begin{tabular}{|l|c|c|}
\hline & Say1 & $\%$ \\
\hline Hiç katılmıyorum & 44 & 2,4 \\
\hline Katılmıyorum & 104 & 5,6 \\
\hline Kararsızım & 100 & 5,4 \\
\hline Kismen kat1lyyorum & 413 & 22,3 \\
\hline Tamamen katıliyorum & 1181 & 63,8 \\
\hline Cevapsız & 10 &, 5 \\
\hline Toplam & 1852 & 100,0 \\
\hline
\end{tabular}


Can, Y. (2015). Üniversite öğrencilerinin aile, cinsiyet rolleri ve kadına yönelik şiddete ilişkin tutumları. International Journal of Social Sciences and Education Research, 1 (1), 163-175.

Tablo 2 incelendiğinde evliliğin tamamen gerekli olduğunu düşünenlerin oranının \%63,8 olduğu görülmektedir. Toplumumuzda evlilik kurumuna verilen önem ortadayken, öğrencilerin evliliğe kısmen mesafeli durmaları dikkatten kaçmamaktadır. Aile ve evlilik gibi birbiriyle bu kadar yakın olan bu iki kavram arasındaki bakış açısı farklılığı, bir tanesinin yani ailenin halihazırda mensup oldukları bir kurum olması, evliliğin ise ileriye dönük yapacakları bir faaliyet olmasıyla ilgili olabilir.

Araştırmanın bu aşamasında öğrencilerin cinsiyet rollerine ilişkin tutumlarına yer verilmiştir. Son yıllarda eğitimde, istihdamda ve yasal düzenlemelerde kadın lehine ortaya çıkan değişim ve gelişmelerin sonucunda artık evde yetki sorumlulukların kadın ile erkek arasında ortak bir paylaşımla yerine getirilmesi tarzına dönüşmüştür. Ancak toplumların zihniyet dünyaları her zaman ekonomik ve sosyal değişme ve gelişmelerle paralel değişmemektedir. Bu nedenle hala evde karar alıcı konumda erkeğin görüldüğü anlayışın öğrenciler arasındaki durumuna bakmakta yarar olabilir

Tablo 3. Ailenin reisi erkektir

\begin{tabular}{|l|c|c|c|c|c|c|}
\hline \multirow{2}{*}{} & \multicolumn{2}{|c|}{ Genel } & \multicolumn{2}{c|}{ Kadın } & \multicolumn{2}{c|}{ Erkek } \\
\cline { 2 - 7 } & Say1 & $\%$ & Say1 & $\%$ & Say1 & $\%$ \\
\hline Hiç katılmıyorum & 274 & 14,8 & 190 & 69,3 & 84 & 30,7 \\
\hline Katılmıyorum & 349 & 18,8 & 242 & 69,3 & 107 & 30,7 \\
\hline Kararsızım & 80 & 4,3 & 48 & 60 & 32 & 40 \\
\hline Kismen katıliyorum & 593 & 32,0 & 298 & 50,3 & 295 & 49,7 \\
\hline Tamamen katıllyorum & 553 & 29,9 & 120 & 21,7 & 433 & 78,3 \\
\hline
\end{tabular}

Ailenin reisinin erkek olduğu yönündeki yargıya kız ve erkek öğrencilerin yaklaşımlarının çok belirgin bir şekilde farklılaştığı görülmektedir. Ailenin reisinin erkek olduğu yönündeki yargıya hiç katılmadığını söyleyen öğrencilerin \%69,3'ü kız iken, bu oran erkek öğrencilerde \%30,7’ye düşmektedir. Ailenin reisinin erkek olduğu yargısına tamamen katıldığını belirtenler arasında ise tam tersi bir durumla karşılaşılmaktadır. Bu yargıya tamamen katıldığını belirten kız öğrencilerin oran $\% 21,7$ iken bu oran erkek öğrencilerde $\% 78,3$ gibi çok yüksek bir orana yükselmektedir. Kadınları toplumsal hayatın her alanındaki ikincil konumlarının şekillenmesine etki eden pek çok ekonomik ve sosyal faktörün yanında, erkeklerin halihazırdaki başat konumlarını yitirmek istemeyişleri ve iktidarlarını kadınlarla paylaşmak istemeyişleri de bir etken olarak karşımıza çıkmaktadır. Kadını kontrol altında tutan ve gücü elinde bulunduran erkek bu kontrolü kaybetmemek için kültürde var olan kadına yönelik olumsuz unsurları pek ala kendi çıkarına kullanabilmektedir. $\mathrm{Bu}$ durum gerek toplumsal ilişkiler boyutunda erkeği öne çıkarma ve kadını ikinci plana itme şeklinde, gerekse de ekonomik alanda üretim ilişkileri boyutunda erkeği daha avantajlı pozisyona yerleştirme şeklinde olabilir. Kadınların istihdama katılımı ilk olarak sermayenin istediği biçimde yani iş güvencesinden yoksun, sosyal güvencesiz ve esnek biçimde, daha sonra da ataerkil normlar uyarınca yani erkeklerin istediği şekilde kadınların ev içi sorumluluklarını da devam ettirerek katılımı öngörülmektedir (Dedeoğlu ve Yaman Öztürk, 2010:45; Ecevit, 1998:267; Demirbilek, 2007:12). 
Can, Y. (2015). Attitude of the university students, family, gender roles and violence towards the women. International Journal of Social Sciences and Education Research, 1 (1), 163-175.

Tablo 4. Ev işleri kadının görevidir

\begin{tabular}{|l|c|c|c|c|c|c|}
\hline \multirow{2}{*}{} & \multicolumn{2}{|c|}{ Genel } & \multicolumn{2}{c|}{ Kadın } & \multicolumn{2}{c|}{ Erkek } \\
\cline { 2 - 7 } & Say1 & $\%$ & Say1 & $\%$ & Say1 & $\%$ \\
\hline Hiç katılmıyorum & 259 & 14,0 & 167 & 64,5 & 92 & 35,5 \\
\hline Katılmıorum & 531 & 28,7 & 306 & 57,6 & 225 & 42,4 \\
\hline Kararsızım & 77 & 4,2 & 29 & 37,7 & 48 & 62,3 \\
\hline Kismen katıliyorum & 662 & 35,7 & 308 & 46,5 & 354 & 53,5 \\
\hline Tamamen katılıyorum & 319 & 17,2 & 90 & 28,2 & 229 & 71,8 \\
\hline
\end{tabular}

Ev işleri kadının görevidir tarzındaki yargıya, tüm öğrenciler göz önünde bulundurulduğunda \%35,7 ile kısmen katılıyorum diyenler en yüksek orana sahiptir. Ancak kız ve erkek öğrencilerin bu soruya verdikleri cevap ayrı ayrı ele alındığında çok dikkat çekici bir tabloyla karşılaşmaktayız. Bu yargıya tamamen katıldığını belirten öğrenciler arasında kızların oranı \%28,2 iken bu oran $\% 71,8$ gibi yüksek bir orana ulaşmaktadır.

Tablo 5. Annenin dışarıda çalışması çocuğu olumsuz etkiler

\begin{tabular}{|l|c|c|c|c|c|c|}
\hline \multirow{2}{*}{} & \multicolumn{2}{|c|}{ Genel } & \multicolumn{2}{c|}{ Kadın } & \multicolumn{2}{c|}{ Erkek } \\
\cline { 2 - 7 } & Say1 & $\%$ & Say1 & $\%$ & Say1 & $\%$ \\
\hline Hiç katılmıorum & 204 & 11,0 & 123 & 60,3 & 181 & 39,7 \\
\hline Katılmıorum & 355 & 19,2 & 221 & 62,3 & 134 & 37,7 \\
\hline Kararsızım & 244 & 13,2 & 118 & 48,4 & 126 & 51,6 \\
\hline Kismen katıllyorum & 695 & 37,5 & 320 & 46 & 375 & 54 \\
\hline Tamamen kat1lyyorum & 350 & 18,9 & 118 & 33,7 & 232 & 66,3 \\
\hline
\end{tabular}

Annenin ev dışında ücretli bir işte çalışmasının çocuğu olumsuz yönde etkileyeceği şeklindeki yargıya katılanların büyük oranda erkek öğrenciler olduğu görülmektedir.Bu yargıya tamamen katıldığını belirten kız öğrencilerin oranı \%33,7 iken, bu oran erkek öğrencilerde iki katına $(\% 66,3)$ çıkmaktadır. Ev işlerinin kadının görevi olduğu yönündeki anlayışta da ortaya çıktığı gibi, burada da erkekler kadını hep evin içerisiyle ve işleriyle ilişkilendirmektedirler. Bu geleneksel ve son derece aşina olduğumuz düzenlemeye göre, koca ekmek parasını kazanır ve aileye maddi kaynakları sağlamak için eve dışarıdan para getirir. Buna karşılık eşi evi temiz tutmak, yemekleri pişirmek, kıyafetleri yıkamak ve çocuklara bakmakla sorumludur (Fine, 2011:97).

Marx gibi sosyologlar kadınların toplumsal hayatta erkekle birlikte kendine bir yer bir statü edinebilmesinin ekonomik faktörlerin etkisi altında, Max Weber gibi sosyologlar ise ekonomik ve sosyal pek çok faktörün etkisi altında şekillendiği belirtmişlerdir (Stones, 2008:55-66). Her iki yaklaşımda da ortak paydanın ekonomik faktörler olduğu görülmektedir.

Kadınların çalışma hayatındaki durumları söz konusu olduğunda en çok üzerinde durulan ve tartışılan konulardan bir tanesi kadınlar ve yöneticilik konusu olmaktadır. Literatürde 'Camdan Tavan' olarak adlandırılan ve başta kadınlar olmak üzere ayrımcılığa maruz kalan insan gruplarını anlatmak üzere kullanılan kavram, çalışma hayatında uygulanan çifte standartçı ve ayrımcı uygulamaları anlatmak için kullanılmaktadır. Literatürde özellikle evli ve çocuklu kadınların çalışma hayatında özellikle yöneticilik pozisyonlarına yükseltilmesinin önündeki bir engel olarak 'Annelik Cezası' kavramına yer verilmiştir. Kadınların kariyerleri açısından cam tavan ve annelik cezası kavramları, özellikle evli ve çocuklu kadınların iş yaşamında erkek meslektaşlarına göre daha az terfi ve ödül alması olgusunu anlatmak için kullanılmaktadır (Başak, 2012:122). Sıradaki soru 
Can, Y. (2015). Üniversite öğrencilerinin aile, cinsiyet rolleri ve kadına yönelik şiddete ilişkin tutumları. International Journal of Social Sciences and Education Research, 1 (1), 163-175.

tam da Cam Tavan ve Annelik Cezası kavramlarıyla birlikte düşünüldüğünde oldukça anlamlı bir durum olan, kadınların yönetici olması konusuna ilişkindir.

Tablo 6. Kadınlar yönetici olmalıdır

\begin{tabular}{|l|c|c|c|c|c|c|}
\hline \multirow{2}{*}{} & \multicolumn{2}{|c|}{ Genel } & \multicolumn{2}{c|}{ Kadın } & \multicolumn{2}{c|}{ Erkek } \\
\cline { 2 - 7 } & Say1 & $\%$ & Say1 & $\%$ & Say1 & $\%$ \\
\hline Hiç katılmıyorum & 131 & 7,1 & 19 & 14,5 & 112 & 85,5 \\
\hline Katılmıyorum & 202 & 10,9 & 60 & 29,7 & 142 & 70,3 \\
\hline Kararsızım & 276 & 14,9 & 91 & 33 & 181 & 67 \\
\hline Kısmen katılıyorum & 639 & 34,5 & 319 & 49,9 & 320 & 50,1 \\
\hline Tamamen katıliyorum & 598 & 32,3 & 409 & 68,4 & 189 & 31,6 \\
\hline
\end{tabular}

Kadınların yönetici olması konusu sürekli tartışmaların odağında olagelen bir konu olmuştur. Bir erkekle aynı eğitim ve tecrübeye sahip olmasına rağmen neden kadınların değil de erkeklerin yöneticilik pozisyonlarına yükseltildikleri hep tartışma konusu olmuştur. Yapılan bazı araştırmalar kadınların da toplumda yerleşik olan anlayışı benimseyerek yönetici olmak istemedikleri yönünde görüş belirttiklerini ortaya çıkarmıştır. Suğur ve Cangöz (2013) tarafından yapılan bir çalışmada kadınlar çalıştıkları kurumda rektör, dekan vb. yönetici pozisyonlarda olmak istemediklerini belirtmişlerdir. Bu araştırmada görüş belirten kadınların genellikle evli ve çalışan kadınlar olduğu düşünüldüğünde, kadınların değişen pozisyonlarına bağlı olarak düşüncelerinin de değişebildiği söylenebilir. Zira bizim araştırmamızdaki kız öğrencilerin çok büyük bir bölümü kadınların yönetici olması gerektiğini belirtmişlerdir $(68,4)$. Erkek öğrencilerin ise büyük oranda $(\% 85,5)$ kadınların yönetici olması düşüncesine sıcak bakmadıkları görülmektedir.

Tablo 7. Kadınlar erkeklerin yaptığı her işi yapabilir

\begin{tabular}{|l|c|c|c|c|c|c|}
\hline \multirow{2}{*}{} & \multicolumn{2}{|c|}{ Genel } & \multicolumn{2}{c|}{ Kadın } & \multicolumn{2}{c|}{ Erkek } \\
\cline { 2 - 7 } & \multicolumn{1}{|c|}{ Say1 } & $\%$ & Say1 & $\%$ & Say1 & $\%$ \\
\hline Hiç katılmıyorum & 286 & 15,4 & 64 & 22,4 & 222 & 77,6 \\
\hline Katılmıyorum & 462 & 24,9 & 200 & 43,3 & 262 & 56,7 \\
\hline Kararsızım & 167 & 9,0 & 72 & 43,1 & 95 & 56,9 \\
\hline Kismen katıliyorum & 654 & 35,3 & 373 & 57 & 281 & 43 \\
\hline Tamamen katıliyorum & 280 & 15,1 & 181 & 69,2 & 89 & 31,8 \\
\hline
\end{tabular}

Temelinde kadın ve erkek arasındaki annelik ve babalık rollerinden kaynaklanan biyolojik işbölümünün olduğu cinsiyet ayrımcı yaklaşım, zaman içerisinde genel bir ayrıma hatta kadınla erkek arasında kadının aleyhine olan bir ayrımcılığa dönüşmüştür. Emeğin toplumsal cinsiyetçi bölünmesi diye tabir edebileceğimiz bu yaklaşım kadınların aleyhine erkeklerinse lehine işlemektedir (Bilton vd, 2008:311). Peki kadınlar belirli mesleklerden nasıl uzak tutulmaktadır? Şirketler bazı işleri 'erkeklerin işi' olarak tanımlayarak, kadınları erkelere göre yetersiz olarak tanımlamaktadırlar. Amerika'daki kömür madenciliğine ilişkin bir çalışmada, çoğu erkeğin madenlerde kadınların çalışmasını anormal bir durum olarak gördüğünü ortaya koymuştur. Madenlerde çalışan kadınlar ise, cinsel yönden rahat veya lezbiyen olarak etiketlemeye maruz kalmaktadırlar. Bu etiketleme kadınların dışlanmasına, işlerini kaybetmelerine neden olmakta ve işlerinde ilerlemelerini neredeyse imkansız hale getirmektedir (Macionis, 2012:335). Özellikle erkek öğrenciler 
Can, Y. (2015). Attitude of the university students, family, gender roles and violence towards the women. International Journal of Social Sciences and Education Research, 1 (1), 163-175.

arasında bu yaklaşımın oldukça benimsendiği görülmektedir. Kadınların erkeklerin çalıştığı mesleklerde çalışabileceği düşüncesine hiç katılmadığını belirten erkek öğrencilerin oranı \% 77,6 olarak karşımıza çıkmaktadır.

Tablo 8. Erkek gerektiğinde eşine şiddet uygulayabilir

\begin{tabular}{|l|l|l|c|c|c|c|}
\hline \multirow{2}{*}{} & \multicolumn{2}{|c|}{ Genel } & \multicolumn{2}{c|}{ Kadın } & \multicolumn{2}{c|}{ Erkek } \\
\cline { 2 - 7 } & \multicolumn{1}{|c|}{ Say1 } & $\%$ & Say1 & $\%$ & Say1 & $\%$ \\
\hline Hiç katılmıyorum & 1419 & 76,6 & 802 & 56,5 & 617 & 43,5 \\
\hline Katılmıyorum & 247 & 13,3 & 64 & 25,9 & 183 & 74,1 \\
\hline Kararsızım & 62 & 3,3 & 9 & 14,5 & 53 & 85,5 \\
\hline Kısmen katılıyorum & 73 & 3,9 & 14 & 19,2 & 59 & 80,8 \\
\hline Tamamen katılıyorum & 43 & 2,3 & 9 & 20,9 & 34 & 79,1 \\
\hline
\end{tabular}

Öğrencilerin geneline baktığımızda erkeğin gerektiğinde eşine şiddet uygulayabileceğine tamamen katıldığını belirtenlerin oranı \%2,3 gibi düşük bir orana sahipken, kız ve erkek öğrencilerin bu konudaki düşüncesine ayrı ayrı baktığımızda bu düşünceye tamamen katıldığını söyleyen kız öğrencilerin oranı \%20,9 iken bu oran erkek öğrencilerde \%79,1 gibi yüksek bir orana çıkmaktadır. Öğrencilere son olarak kadına yönelik şiddetin nedenleri sizce nedir diye sorulmuş ve cevapların dağılımı aşă̆ıdaki tabloda verilmiştir.

Tablo 9. Kadına yönelik şiddetin nedenleri

\begin{tabular}{|l|c|c|}
\hline & Say1 & $\%$ \\
\hline Eğitimsizlik & 275 & 14,8 \\
\hline Alkol & 9 &, 5 \\
\hline Ekonomik Sorunlar & 52 & 2,8 \\
\hline Kadınların Aşırı Eleştirel Tutumları & 21 & 1,1 \\
\hline Erkeklerin Psikolojik Sorunları & 38 & 2,1 \\
\hline Kadının Ekonomik Olarak Erkeğe Bağımlı Olması & 4 &, 2 \\
\hline Gelenekler ve Toplumun Değer Yargıları & 109 & 5,9 \\
\hline Kıskançlık, Aldatma, & 28 & 1,5 \\
\hline Eşler Arası Geçimsizlik & 37 & 2,0 \\
\hline Cezaların Caydırıcı Olmaması & 19 & 1,0 \\
\hline Medya Etkisi & 13 &, 7 \\
\hline Kadınların Görevlerini İhmal Etmeleri & 9 &, 5 \\
\hline Kadınların Erkekler Tarafindan Güçsüz Görülmesi & 67 & 3,6 \\
\hline Dini İnanç Eksikliği & 8 &, 4 \\
\hline Kadınların Kendilerine Güvenlerinin Olmaması & 6 &, 3 \\
\hline Kadınların Giyimlerine Dikkat Etmemesi & 3 &, 2 \\
\hline Eşler Arasında Saygının Olmaması & 22 & 1,2 \\
\hline
\end{tabular}

Kadına yönelik şiddetin nedenleri olarak çok farklı etkenler ileri sürülmüştür. Ancak yüksek orana sahip nedenler arasında \%14,8 ile eğitimsizlik ilk sırayı almaktadır. Onu \%5,9 ile gelenekler ve toplumun değer yargıları ile kadınların erkekler tarafından güçsüz görülmesi izlemektedir $(\% 3,6)$. 
Can, Y. (2015). Üniversite öğrencilerinin aile, cinsiyet rolleri ve kadına yönelik şiddete ilişkin tutumları. International Journal of Social Sciences and Education Research, 1 (1), 163-175.

\section{Sonuç}

Üniversite öğrencilerinin aile, cinsiyet rolleri ve kadına şiddetin nedenlerine ilişkin tutumlarını belirlemeye yönelik olarak yapılan bu çalışmada; öğrencilerin aile kurumuna yönelik çok olumlu tutumlara sahip oldukları ancak kendi ailelerini kurmak anlamına gelen evliliğe çok da sıcak bakmadıkları görülmüştür. Kadın ve erkek arasındaki ilişkileri ve kadın ve erkeğin toplumdaki rol ve konumlarını belirlemeye dönük olarak sorulan sorulara verilen cevaplarda erkek ve kız öğrenciler açısından belirgin farklılıklar ortaya çıkmıştır. Ataerkil cinsiyet ayrımcı tutumların erkek öğrenciler arasında daha yaygın olduğu belirlenmiştir. Kadına şiddetin başlıca nedenleri olarak; eğitimsizlik, toplumun değer yargıları, erkeklerin kadınlara yönelik olumsuz akış açısı gösterilmiştir.

$\mathrm{Bu}$ bulgulardan hareketle aile kurumuna karşı yüksek düzeyde olumlu tutum besleyen üniversite öğrencilerinin evlilik söz konusu olduğunda neden olumsuz bir tutum içine girdiklerinin nedenleri daha derinlemesine başka araştırmalarla ortaya konularak bununla ilgili tespitlere ulaşılmalı ve gerekli girişimler yapılmalıdır. Üniversite öğrencileri örneğinden hareketle erkeklerde var olmaya devam eden kadınlara yönelik cinsiyet ayrımcı yaklaşımların azaltılması adına aileden başlamak üzere tüm toplumda bir eğitim seferberliği başlatılmalıdır. Kadına yönelik şiddetin nedenleri arasında ilk sırada eğitim sorununun gösterilmiş olması da bu konuda bize adeta anlamlı bir mesaj vermektedir. Cinsiyet ayrımcılığı ve kadına şiddet konusundaki duyarlılığı artırmaya, olumsuz değer yargılarını, erkeklerden kadınlara yönelik ortaya çıkan olumsuz bakış açılarını ve önyargıları ortadan kaldırmaya dönük yoğun bir çabanın içine girilmesi ve bir eğitim seferberliği başlatılması gerekmektedir.

\section{Kaynakça}

Abrahamson, M. (1990). İşlevselcilik, Çev. Nilgün Çelebi, Konya: Sebat Ofset.

Başak, S. (2009). Cam Tavanlar, KÖK Araştırmalar KÖK Sosyal ve Stratejik Araştırmalar Dergisi, Cilt XI, Sayı 2, s. 119-132.

Bilton, T. vd. (2008). Sosyoloji, Anakara: Siyasal Yayinevi.

Bora, A. ve Üstün İ. (2008). 'Sıcak Aile Ortamı' Demokratikleşme Sürecinde Kadın ve Erkek, İstanbul: TESEV Yayınları.

Çaha, Ö. (2010). Sivil Kadın Türkiye'de Kadın ve Sivil Toplum, Ankara: Savaş Yayınevi.

Dedeoğlu,S. ve Yaman Öztürk M. (2010). Kapitalizm Ataerkillik ve Kadın Emeği, SAV Yayınları, İstanbul.

Demirbilek, S. (2007). Cinsiyet Ayrımcılığının Sosyolojik Açıdan Incelenmesi, Finans Politik\&Ekonomik Yorumlar, Cilt 44, Say1 511,s.11-27.

Durudoğan, H. vd. (2010). 'Türkiye'de Kırsal Kadının Toplumsal Konumu', Türkiye'de Toplumsal Cinsiyet Çalışmaları Eşitsizlikler Mücadeleler Kazanımlar, Koç Üniversitesi Yayınları, İstanbul.

Ecevit, Y. (1998). Türkiye'de Ücretli Kadın Emeğinin Toplumsal Cinsiyet Temelinde Analizi, 75 Y1lda Kadınlar ve Erkekler, Toplumsal Tarih Vakfi Yayınları, İstanbul.

Ecevit, Y. (2003). Toplumsal Cinsiyetle Yoksulluk İlişsisi Nasıl Kurulabilir? Bu İlişki Nasıl Çallşılabilir? C.Ü. Tıp Fakültesi Dergisi 25 (4) Özel Eki, s.83-88.

Fine, C. (2011). Toplumsal Cinsiyet Yanılsaması, Çeviri; Kıvanç Tanrıyar, İstanbul: Sel Yayıncılık).

Giddens, A. (2012). Sosyoloji, İstanbul: Kırmızı Yayınları.

Hesse-Biber, S. (1999). Introduction, Feminist Approaches to Theory and Methodology, New York Oxford: Oxford University Press. 
Can, Y. (2015). Attitude of the university students, family, gender roles and violence towards the women. International Journal of Social Sciences and Education Research, 1 (1), 163-175.

Kandiyoti, D. (1999). Islam and Patriarchy: A Comparative Perspective, Feminist Approaches to Theory and Methodology, New York Oxford: Oxford University Press.

Köse, A. (2009). Siyasal İletişim Aracı Olarak Lider Eşlerinin Temsili: 1973 Genel Seçim Çalışmaları Örneğinde Siyasi Lider Eşi Olarak Nazmiye Demirel ve Rahşan Ecevit'in Temsili, İstanbul Üniversitesi İletişim Fakültesi Dergisi, Sayı 35, s. 81-92.

Macionis, J.J. (2012). Sosyoloji, Ankara: Nobel Yayınevi.

Marshall, G. (1999). Sosyoloji Sözlüğü, Çev. Osman Akınhay ve Derya Kömürcü, Ankara: Bilim ve Sanat Yayınları.

Ökten, Ş. (2009). Toplumsal Cinsiyet ve İktidar: Güneydoğu Anadolu Bölgesinin Toplumsal Cinsiyet Düzeni, Uluslar arası Sosyal Araştırmalar Dergisi, Cilt 2, Sayı 8, s. 302-312.

Özgüven, İ.E. (2001). Ailede İletişim ve Yaşam, Ankara: PDREM Yayınları. 
Can, Y. (2015). Üniversite öğrencilerinin aile, cinsiyet rolleri ve kadına yönelik şiddete ilişkin tutumları. International Journal of Social Sciences and Education Research, 1 (1), 163-175.

\section{Extended abstract in English}

For three decades, feminist research has been explicity connected with interdisciplinary. This linkage was initially motivated by the recognition of two realities: the fields of knowledge that had sprung up within disciplinary terrains largely reflected male interests, and the artificial barriers diving this domain obstructed a complete view of women's situations and the social structures that perpetuated gender inequalities. Many years before feminist scholar began to imagine that they might engender the the disciplines, they set out to make the disciplinary landscapes more hospitable to feminist analysis and interpretation (Hesse-Biber, 1999:1).

In contrast to the growing body of historical scholarship on gender relations in the West, the question of women in Muslim societies has remained closely tied to a predominantly ahistorical consideration of the main tenets of Islamic religion and their implications for women. This has been attributed by some to the more general shortcomings of Middle Eastern historiography, namely the the lingering influence of orientalism and idealist bias that presents historical facts as flowing directly from ideology. In the case of scholarship on women, these tendencies have been compounded by a high degree of confusion between plomical and analytical goals. There is a continuing output of exegetical writing by Muslim scholars many of whom identity themselves of feminists. This writing typically tries to establish Islam's compatibility with the emancipation of women. The favoured sources of such works continue to be the Quran, the hadith of the lives of prominent women in early Islam (Kandiyoti, 1999:219).

Family is one of the essential institutions constituting the social structure. It is well-known that the family as an institution undertakes several functions regarding with both individual and society. The family has its own importance due to its functions on its members' achieving economic sexual and psychological achievements in addition to transferring the society's values to the new generations and providing continuity of human kind and civilization.

The family is a fundamental social institution which is subject to various reviews including both positive and negative ones. There have been different points of views regarding family. On the one side, some believe that today the family has already transferred its various functions such as economic and social ones to some other agencies; and even writing a book called "the death of the family" they stressed that it is no longer a necessity for us. On the other side, some argue that the family will never lose its significance due to its functions in preserving children and adolescent groups from alcoholism, drugs, and sexuality at a young age. They have also acknowledged that in achieving children's emotional satisfaction the family has no alternative. They regard the family as a crucial institution in the socialization of individuals and sustainability of social structure. The family is a determining factor in the formation of personality as well as attitudes in a variety of situations. The family environment in which the individual is born regenerates itself by transferring its peculiar subculture elements to the individual. Therefore, the family struggles to protect its entity and entirety. The characteristics of the family gives us a hint about what kind of personality the individual will have.

However, it has been observed that the discussions regarding family have been trapped between two contradictory approaches. The first one has underestimated the family by seeing it as one of the main responsible agents for social problems. The second one, conversely, has tended to mythicize it and shown almost zero tolerance to criticism. Beyond such standpoints, it must be plausible to understand that how this long-standing institution has been affected by social transformations and 
Can, Y. (2015). Attitude of the university students, family, gender roles and violence towards the women. International Journal of Social Sciences and Education Research, 1 (1), 163-175.

how this evolution has occurred in the course of time. Obviously, such an attempt might be possible through ever-increasing research efforts upon the family institution. This research has been emerged as a result of such an effort. The subject of this research is the attitudes of university students on family, marriage, gender roles, and the causes of violence against women. The population of the research covers the students of Niğde University and it has been constructed via current enrolment lists received from the Office of the Vice President for Student Affairs in December, 2014. The lists include the current number of students at faculties, vocational schools, institutes, and conservatory. Based on the numbers of boys and girls at each faculty, department and class, and assuming each class as a stratum, a stratified sampling has been constructed. $10 \%$ of the total number of students in each layer selected by random sampling method and a questionnaire has been applied to this group. The findings show that the students ascribe a considerable amount of value to the family institution. Their attitudes towards marriage, on the contrary, are not equally positive. The students have asserted various reasons towards the reasons of violence against women but the prominent ones described as follows: lack of education, traditions, social values, prejudices of men, and economic problems. It must start an education campaign overall gender discrimination and violence against women. 